\title{
The bromoquinone annulation reaction: a formal total synthesis of EO9
}

\author{
Eamon Comer and William S. Murphy \\ Department of Chemistry, University College Cork, Cork, Ireland \\ Email: l.murphy@eircom.net
}

Dedicated to Professor M. Anthony McKervey on his $65^{\text {th }}$ birthday

(received 20 Mar 03; accepted 18 Jun 03; published on the web 20 Jun 03)

\begin{abstract}
The following report describes a one-pot regiospecific annulation reaction in the production of a highly advanced EO9 precursor. This intermediate is modified in what constitutes the shortest total synthesis of the EO9 antitumor drug.
\end{abstract}

Keywords: EO9 synthesis, bromoquinone annulation, regiospecific

\section{Introduction}

The indoloquinone EO9 is a synthetic quinone, based on the clinically used anti-cancer agent mitomycin C (MMC). One of the most interesting and studied aspects of the mitomycins is their extraordinary mechanism of antitumor activity. The involvement of these drugs in the formation of cross-linked DNA is dependent on the presence of either chemical or enzymatic reducing agents. Like mitomycin C, EO9 is also activated bioreductively. Bioreductive alkylating agents exhibit selective toxicity towards hypoxic cells both in vitro and in vivo. ${ }^{1}$ Hypoxic cells are resistant to radiotherapy and so drugs that target these cells are of major importance. ${ }^{2}$

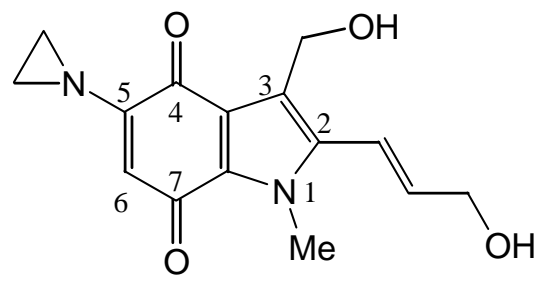

1

EO9

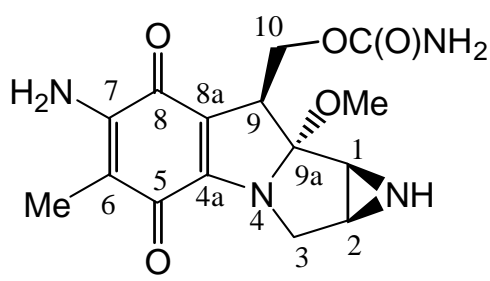

2

Mitomycin C (MMC) 
EO9 was discovered and selected by the new drug development office at the European Organization for Research and Treatment of Cancer (EORTC) as a new bioreductive drug for clinical trials on account of its antitumor properties. Phase I clinical studies were started in 1992 in a three-weekly schedule, where a number of patients experienced some decreased kidney function. Nonetheless, phase II trials started in the summer of 1994. In 2000 the results of new phase I trials were announced using EO9 in a weekly schedule, which showed no major organ toxicity. ${ }^{3}$ Compared to MMC, EO9 exhibits higher in vitro potency, a different range of activity and a greater degree of selectivity for hypoxic tumour cells. The drug currently trades under the name Neoquin ${ }^{\mathrm{TM}}$.<smiles></smiles>

\section{Scheme 1}

In these laboratories a bromoquinone-enamine annulation reaction was discovered by which mitosenes such as 5 could be prepared regiospecifically (Scheme 1). ${ }^{4}$ We chose to apply this methodology towards a one pot synthesis of the highly functionalised indoloquinone 6 . Retrosynthetic analysis of EO9 suggested that this novel quinone could be a key intermediate in a new fast-track synthesis of EO9 (Scheme 2).

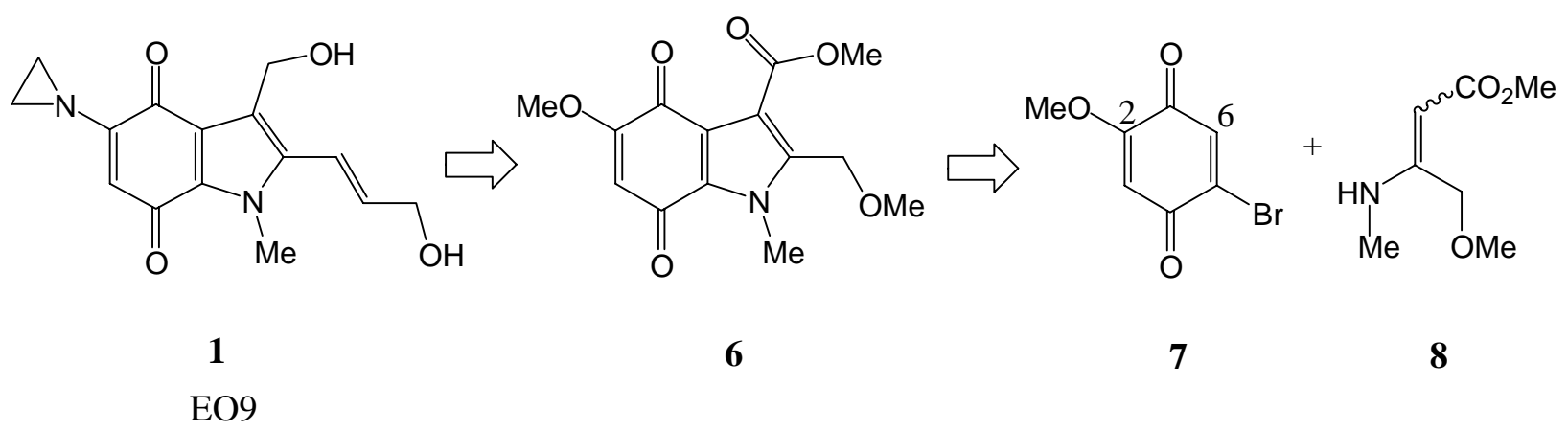

\section{Scheme 2}




\section{Results and Discussion}

The annulation precursor 7 was available ${ }^{5}$ from commercially available materials in 3 steps in $50 \%$ yield. Enamino ester 8, as a mixture of E- and Z- isomers, was prepared in high yield by passing methylamine gas through 4-methoxy acetoacetate. ${ }^{6}$ Thus a solution of $\mathbf{8}$ in acetonitrile was added to a suspension of $7, \mathrm{~K}_{2} \mathrm{CO}_{3}$ (3.5 equ) and $\mathrm{CuBr}_{2}(0.2 \mathrm{equ})$ in the same solvent. This produced an unclean reaction, however, upon work-up and purification the annulated product 6 was obtained in $10 \%$ yield. Optimisation studies led to the discovery that the use of 1.5 equivalents of 7 increased the yield of indoloquinone $\mathbf{6}$ to $17 \%$ and that heating the mixture to $50{ }^{\circ} \mathrm{C}$ reduced the reaction time from 4 weeks to $28 \mathrm{~h}$.

The initial step of the annulation reaction is the Michael addition of 8 to C6 of the bromoquinone 7. From our work ${ }^{8}$ in these laboratories and related studies ${ }^{4 a}$, we have shown that a major role for the $\mathrm{CuBr}_{2}$ is to oxidise the hydroquinone produced in the initial Michael reaction to the corresponding quinone under aerobic conditions. The $\mathrm{CuBr}_{2}$ may also adopt the role of Lewis acid. It seemed reasonable to us then, to carry out the reaction in two stages. We anticipated the isolation of the intermediate quinone in stage one and in the second stage in the presence of catalyst, the ring-closed annulated product. Our hope was that this two-step approach might lead to a cleaner reaction and an increase in the yield of $\mathbf{6}$. Thus equimolar quantities of $\mathbf{7}$ and 8 were combined in methanol and the solution heated to $50{ }^{\circ} \mathrm{C}$. After $16 \mathrm{~h}$ heating, the indoloquinone 6 was isolated in $20 \%$ yield accompanied by two other major products. To the best of our knowledge this is the first example of an annulation reaction of this type successfully performed in the absence of catalyst or base. A limited optimisation study of this new procedure was undertaken. We found that the most efficient procedure involved the heating of 1.3 equivalents of 7 and 1 equivalent of 8 at $50^{\circ} \mathrm{C}$ in methanol (or ethanol) for 16 h. This provided 6 in $23 \%$ yield. This represented a 2.3 fold increase on our initial procedure using a catalyst and base.

Regiospecificity is a key element of our annulation reaction. To confirm this, we undertook a synthesis of the regioisomer 11. Thus, 9 was synthesised in accordance with a literature procedure in three steps. ${ }^{7}$ Close independent examination of the ${ }^{1} \mathrm{H}$ NMR of $\mathbf{7}$ and $\mathbf{9}$ showed that each was a pure regioisomer. However, when equimolar quantities of $\mathbf{9}$ and enamino ester $\mathbf{8}$ were dissolved in methanol at room temperature a remarkable transformation took place. The substrates reacted rapidly to produce the Michael adduct $\mathbf{1 0}$ (in the Z-form) as a purple solid in $73 \%$ yield along with the annulated product $\mathbf{1 1}$ as a yellow solid in $28 \%$ yield (Scheme 3 ). Thus contrary to our experience in the preparation of indoloquinone $\mathbf{6}$, in which the reaction went to completion only after 16 hours heating in methanol, in this case the starting material had fully reacted in less than four minutes at room temperature.

The adduct 10 was then treated with $\mathrm{CuBr}_{2}$ and $\mathrm{K}_{2} \mathrm{CO}_{3}$ and the mixture stirred at room temperature for $24 \mathrm{~h}$. This provided 11 in 54\% yield as a bright yellow solid. Overall, the annulated compound was isolated in 69\% yield. 


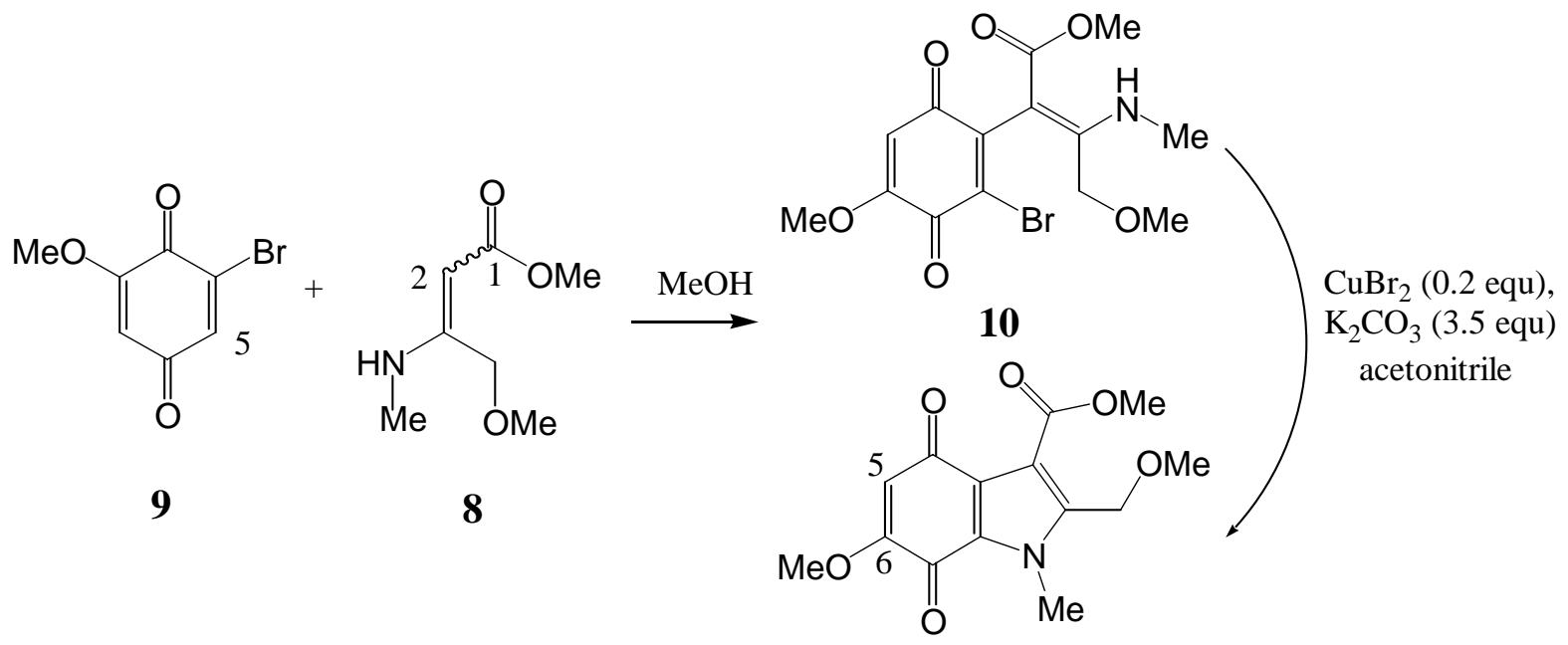

11

\section{Scheme 3}

The ${ }^{1} \mathrm{H}$ NMR spectra of the regioisomers $\mathbf{6}$ and $\mathbf{1 1}$ were carefully studied. The largest shift in signals arose from the substituents on the 5- and 6-positions of the quinone ring. This is not surprising when one considers in detail the resonance forms of the indoloquinone $6{ }^{8}$ The H6 proton in $\mathbf{6}$ resonated at $5.71 \mathrm{ppm}$, while the $\mathrm{H} 5$ proton in $\mathbf{1 1}$ produced a signal at $5.76 \mathrm{ppm}$. In the ${ }^{1} \mathrm{H}$ NMR of 6 no trace of absorption could be observed at $5.76 \mathrm{ppm}$. Similarly, inspection of the ${ }^{1} \mathrm{H}$ NMR of 11 showed no sign of a signal at $5.71 \mathrm{ppm}$. In order to determine whether the quinone proton signals of a mixture of $\mathbf{6}$ and $\mathbf{1 1}$ would be clearly resolved in a ${ }^{1} \mathrm{H} \mathrm{NMR}$, increasing quantities of $\mathbf{1 1}$ were added to a pure sample of $\mathbf{6}$. The two signals are well resolved when the regioisomer $\mathbf{1 1}$ is present in $3 \%, 8 \%, 22 \%$ and $43 \%$ of the total mixture. Thus, we can conclude that the reaction of enamino ester $\mathbf{8}$ with either quinone $\mathbf{7}$ or $\mathbf{9}$ under the conditions specified above, produces the highly functionalised indolequinones $\mathbf{6}$ and 11, regiospecifically.

It must be asked why there is such a striking disparity in reactivity between the two regioisomeric quinones? The differences can be rationalised by considering the resonance forms of the two quinone structures 7 and $\mathbf{9}$ (Figure 1). In the case of $\mathbf{7}$ the favoured 5-position is blocked by the bromine atom so that nucleophilic attack takes place at the next most favoured site, C6. However, as can be seen below, an efficient Michael addition at this position is inhibited by the strong contributions of resonance form $7 \mathbf{a}$.

In the case of $\mathbf{9}$ a resonance form (9a) can be drawn in which a positive charge is generated on C5. This resonance effect in addition to the inductive effect of the bromine atom on C6 results in a partial positive charge at the 5-position. Consequently nucleophilic attack is facilitated at this site and the Michael addition occurs efficiently. The isolation of $\mathbf{1 0}$ was crucial to our understanding of the reaction mechanism. This proved that initial attack via $\mathrm{N}$-addition of $\mathbf{8}$ on the bromine bearing carbon of $\mathbf{9}$, followed by ring closure to give $\mathbf{1 1}$, as the prominent pathway, did not take place. Although a similar intermediate was not isolated during the preparation of $\mathbf{6}$ it 
is presumed that the same mechanism was involved. Thus, we propose that the key steps in this synthesis are (a) the Michael addition of 8 to C6 of 7 as shown in Scheme 4 to give hydroquinone 12 after enolisation, (b) air oxidation of the hydroquinone to afford quinone 13 and (c) cyclisation to $\mathbf{6}$.

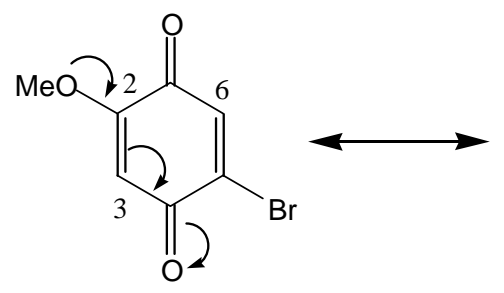

7

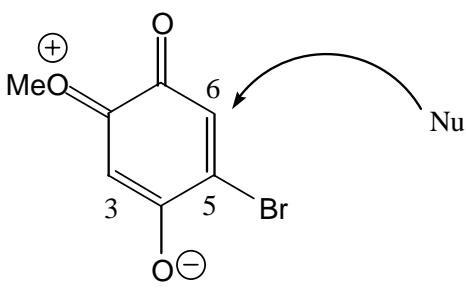

$7 \mathbf{a}$
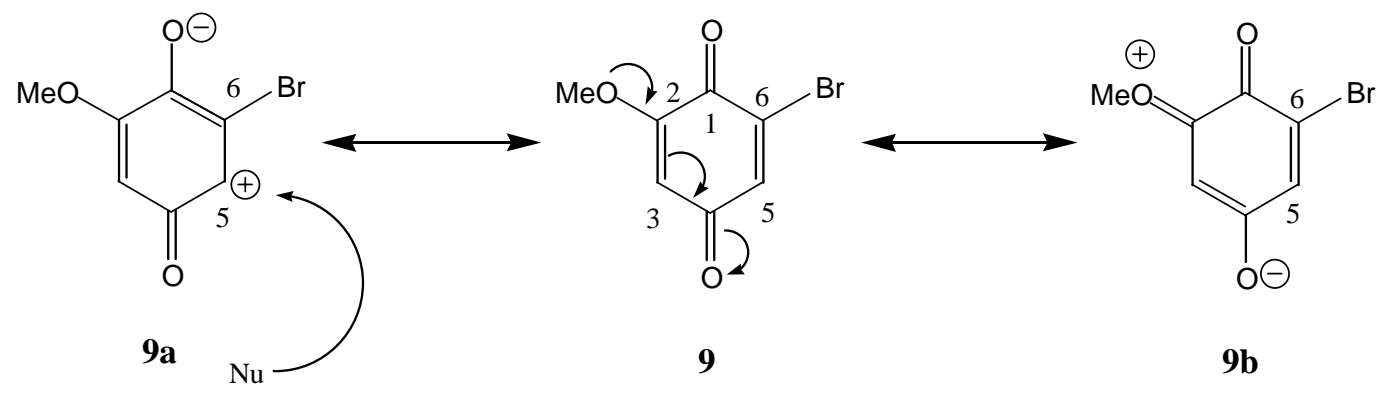

Figure 1. Resonance forms quinones 7 and $\mathbf{9}$.

The quinone adduct $\mathbf{1 0}$ (regioisomer of 13) was isolated exclusively as the Z-isomer. We were enabled to assigned this configuration from the studies of Murphy and O'Sullivan ${ }^{4 a}$, Luly and Rapoport ${ }^{9}$ and of our own spectral studies on E- and Z- enaminoester 8 and related compounds $^{8}$, which closely corresponded with those of Dudek and Volpp ${ }^{10}$. The spectral difference between the isomers is largely the result of the $\mathrm{NH}$ bond hydrogen bonding with the ester carbonyl. Pronounced differences are clearly detectable between the ${ }^{1} \mathrm{H}$ NMR chemical shifts of both the $\mathrm{NH}$ and the allylic methylene protons and the infrared carbonyl stretching frequency for each geometrical isomer.

In the Z-configuration however, the nitrogen atom of the enamine system was unable to attack the bromine bearing carbon, thus preventing ring closure. Clearly facile isomerisation about the double bond was involved. The ease of such a pathway can be understood by considering delocalisation of the lone pair of electrons of the nitrogen atom of $\mathbf{1 3}$ onto the ester carbonyl group. The final cyclisation step occurs by addition of the nitrogen to the brominebearing carbon followed by elimination of $\mathrm{HBr}$. Baldwin's predicts this addition-elimination step rules for ring closure, to be a disfavoured process since it involves 5-endo-trig ring closure. ${ }^{11}$ However, this rationale ignores the highly polarised nature of groundstate $\mathbf{1 4}$ (Scheme 4). 
With the indoloquinone 6 in hand, the conjugated diester EO14 17 seemed a reasonable synthetic target and was in itself an important compound. ${ }^{12}$ More importantly, it could be efficiently converted to EO9 in just four steps. ${ }^{12}$

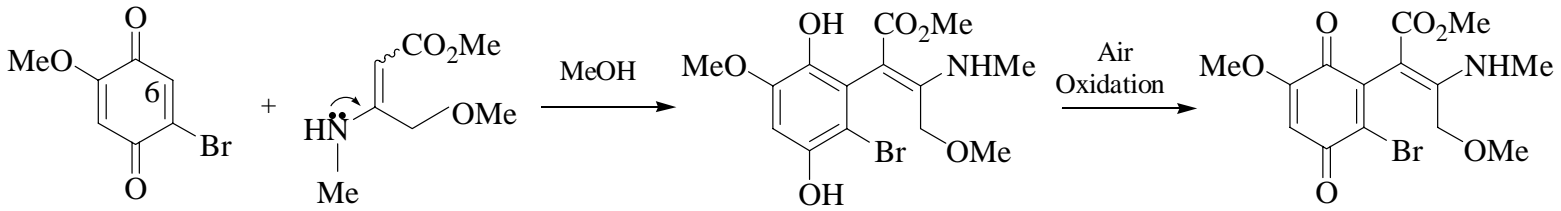

7

8
12

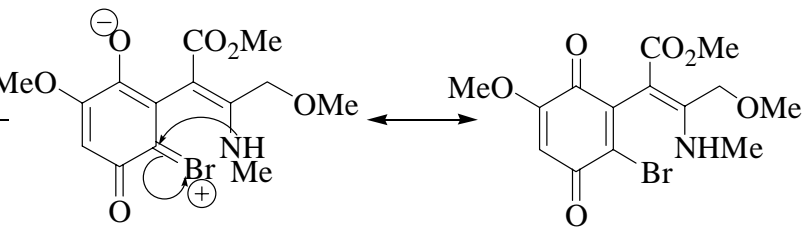

14a
13

14

\section{Scheme 4}

Benzylic oxidation by DDQ has been well studied by many groups involving relatively electron rich systems. ${ }^{13}$ It was initially feared that $\mathbf{6}$ would be too strongly electron deficient to achieve oxidation to the aldehyde. Initial experiments seemed to confirm this hypothesis. However, when 6 was treated with 5.4 equivalents of DDQ in a mixture of methylene chloride and water (18: 1) the aldehyde $\mathbf{1 6}$ was isolated in $\mathbf{8 8 \%}$ yield. It remained for us to olefinate the aldehyde moiety in the latter to achieve a formal total synthesis of EO9. We hoped to accomplish this final step by means of the Wadsworth-Emmons reaction (HWE), using the modification of Rathke and Nowak ${ }^{14}$, also used by Kasai ${ }^{15}$. This procedure meant that a relatively weak base could be used in the HWE reaction. This was important in our system as the traditional bases for the HWE reaction such as $n$-butyllithium or sodium hydride could react with the base sensitive quinone moiety in 16. In this fashion the E-olefin 17 was obtained in $90 \%$ yield.

The advanced quinone $\mathbf{1 7}$ is a key intermediate in the synthesis of EO9. It had been prepared previously in a total of seventeen steps by Speckamp and Oostveen. ${ }^{12}$ The immediate precursor of EO9 is the 5-methoxyindolequinone 19, a compound known as EO7. This is available from 17 by way of protection of the quinone using sodium dithionite, reduction of the ester functionalities and oxidation of the hydroquinone to give EO7 in 55\% yield, using the method of Speckamp and Oostveen. ${ }^{12}$ Alternatively, Kasai and co-workers ${ }^{15}$ using the mixed ester 18 produced 19 in $76 \%$ yield by means of protection, reduction and air oxidation of the hydroquinone intermediate. EO7 is then simply converted into EO9 1 by reaction with ethyleneimine in acetonitrile. ${ }^{15}$ 


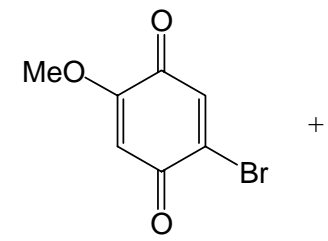

7

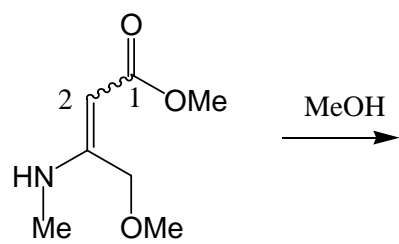

8<smiles>COCc1c(C(=O)OC)c2c(n1C)C(=O)C=C(OC)C2=O</smiles>

6<smiles>COC(=O)c1c2c(n(C)c1C=O)C(=O)C=C(OC)C2=O</smiles>

16

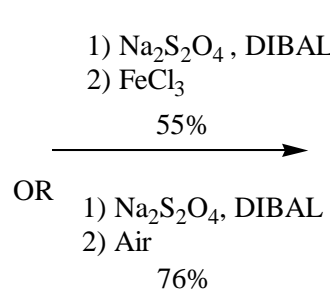

19

EO7

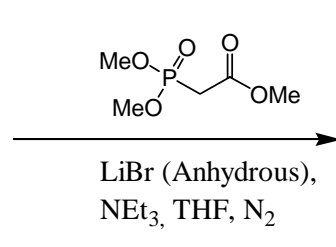

$\mathrm{NEt}_{3}$, THF, $\mathrm{N}_{2}$

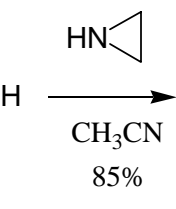

$85 \%$<smiles>[R]OC(=O)/C=C/c1c(C(=O)OC)c2c(n1C)C(=O)C=C(OC)C2=O</smiles>

17 (EO14) $\mathrm{R}=\mathrm{Me}$

18

$\mathrm{R}=\mathrm{Et}$

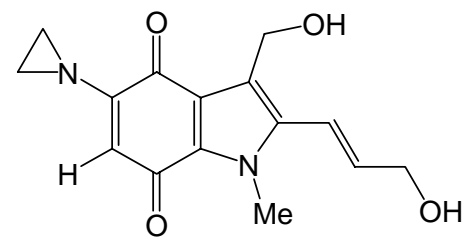

1

EO9

\section{Scheme 5}

Consequently, our overall route to EO9 is short, being just 6 steps from enamino ester $\mathbf{8}$ in an overall yield of $9 \%$. Our new sequence compares favourably with the previous published syntheses of EO9. The original procedure of Speckamp and Oostveen ${ }^{12}$ requires a total of 21 steps to give 1 in 6\% overall yield. More recently, Moody and co-workers ${ }^{16}$ reported the formal synthesis of EO9, however, some hazardous reagents were used and it required 15 steps from ortho-vanillin to give $\mathbf{1}$ in 1.4\% overall yield. Around this time an alternative total synthesis was announced by Kasai and co-workers ${ }^{15}$ which provided EO9 in 10 steps in 13\% overall yield. Thus we can report the shortest known synthetic route to EO9. Our overall yield is superior to previous preparations with the exception of Kasai's total synthesis in 1996. Our route, however, offers a much more rapid entry to E09, being just 6 steps from methyl 3-methylamino-4methoxybut-2-enoate 8. This is to be compared to Kasai's method which involves 10 steps from practically the same enamino ester, methyl 3-amino-4-methoxybut-2-enoate.

In conclusion the authors present the shortest known synthesis of the important compound EO9. Additionally, the rapid entry into highly functionalised compounds, which our procedure 
allows, makes this synthesis ideally and uniquely suited to the preparation of analogues to EO9, should they become targets in the future.

\section{Experimental Section}

General Procedures. NMR spectra were recorded on a Bruker AVANCE 300 spectrometer in $\mathrm{CDCl}_{3}$ with TMS as internal standard. Chemical shifts $\left(\delta_{\mathrm{H}}\right.$ and $\left.\delta_{\mathrm{C}}\right)$ are expressed as parts per million (ppm).

Mass spectra were scanned on a Kratos Profile spectrometer at the energy of ionising electrons equal to $70 \mathrm{eV}$. The mass spectrum of sample $\mathbf{1 7}$ was scanned using a Micromass LCT time of flight mass spectrometer at a cone voltage of $35 \mathrm{~V}$.

The Microanalysis Laboratory, University College Cork, using a Perkin Elmer 240 and an Exeter Analytical CE440 elemental analyser, performed elemental analyses.

Infrared (IR) spectra were recorded on a Perkin-Elmer FT-IR Paragon 1000.

Preparation of methyl 3-methylamino-4-methoxybut-2-enoate (8). A rapid stream of methylamine gas was passed through a solution of 4-methoxyacetoacetate (17.60 g, $121 \mathrm{mmol})$ with constant stirring for $2.5 \mathrm{~h}$. Diethyl ether $\left(20 \mathrm{~cm}^{3}\right)$ was added and the water that had formed during the reaction was separated. The ether solution was dried $\left(\mathrm{MgSO}_{4}\right)$, filtered and the solvent removed under reduced pressure. The resultant oily residue was distilled under reduced pressure and the distillate placed in the fridge for 3 days to afford methyl 3-methylamino-4-methoxybut2-enoate 8 (16.7 $\mathrm{g}, 87 \%$ ) as a pale yellow low melting solid as a mixture of $\mathrm{E}$ and $\mathrm{Z}$ isomers (ratio 58: 42), m.p. $32-38{ }^{\circ} \mathrm{C}$; b.p. $54-56{ }^{\circ} \mathrm{C} / 0.5 \mathrm{mmHg}$ (Found: C, 53.0; H, 7.9; N, 9.10. $\mathrm{C}_{7} \mathrm{H}_{13} \mathrm{NO}_{3}$ requires C, 52.80; H, 8.20; N, 8.80\%); $v_{\max }\left(\right.$ film) $/ \mathrm{cm}^{-1} 3385,1672,1590$ and 1160; $\delta_{\mathrm{H}}$ 2.75 (d, 3H, J = $5.1 \mathrm{~Hz}, \mathrm{NMe}$ ), 3.43 (s, 3H, 4-OMe), 3.64 (s, 3H, $\mathrm{CO}_{2} \mathrm{Me}$ ), 4.50 (s, 1H, vinyl proton), 4.69 (s, 2H, 4-CH $\mathrm{CH}_{2}$ ) 5.81 (s, $\left.1 \mathrm{H}, \mathrm{NH}\right) \delta_{\mathrm{C}} 29.61$ (NMe), 50.24 (4-OMe), $58.25\left(\mathrm{CO}_{2} \mathrm{Me}\right.$ ), 71.55 (4- $\mathrm{CH}_{2}$ ), 79.06 (C-2), 82.75, 160.40, and 169.19. (Note: Resonances due to both $\mathrm{E}$ and $\mathrm{Z}$ isomers were present in a 58:42 ratio in $\mathrm{CDCl}_{3}$, however only the major series of peaks are included).

Preparation of methyl 5-methoxy-2-methoxymethyl- $N$-methyl-4,7-dioxo-indole-3carboxylate (6). To a solution of quinone 7 (282 $\mathrm{mg}, 1.3 \mathrm{mmol}$ ) in methanol $\left(25 \mathrm{~cm}^{3}\right)$ was added enamino ester 8 (159 mg, $1 \mathrm{mmol})$. The reaction solution was stirred at $50{ }^{\circ} \mathrm{C}$, while open to the atmosphere, for $16 \mathrm{~h}$. The yellow solution darkened over this time period to produce a black reaction mixture. The solution was allowed to cool to room temperature and the solvent was evaporated under reduced pressure to produce a crude solid. This solid was purified by flash chromatography with silica gel, eluting with EtOAc/hexane (30: 70) to afford the title compound 6 as a bright yellow solid (67 mg, 23\% yield). m.p.148-150 ${ }^{\circ} \mathrm{C}$ (from propan-2-ol) (Found: C, 57.1; H, 5.0; N, 4.9; $\mathrm{M}^{+}$, 293.0878. $\mathrm{C}_{14} \mathrm{H}_{15} \mathrm{NO}_{6}$ requires $\mathrm{C}$, 57.3; H, 5.1; N, 4.8\%; M, 293.0899); $v_{\max }(\mathrm{KBr}) / \mathrm{cm}^{-1}$ 2924, 1710, 1688, 1641, 1608 and 1105; $\delta_{\mathrm{H}} 3.37$ (s, 3H, NMe), 3.83 (s, 3H, 
$\mathrm{CH}_{2} \mathrm{OMe}$ ), 3.91 (s, 3H, 5-OMe), 4.02 (s, 3H, $\mathrm{CO}_{2} \mathrm{Me}$ ), 4.68 (s, 2H, $\underline{\mathrm{C}}_{2}-\mathrm{OMe}$ ), 5.71 (s, 1H, 6$\mathrm{H}) ; \delta_{\mathrm{C}} 33.26(\mathrm{NMe}), 52.16\left(\mathrm{CH}_{2}-\mathrm{OMe}\right), 56.67\left(\mathrm{CO}_{2} \underline{\mathrm{Me}}\right), 58.08$ (5-OMe), 62.41 ( $\left.\underline{\mathrm{CH}}_{2}-\mathrm{OMe}\right)$, 106.32 (CH), 114.93 (C), 121.10 (C), 130.55 (C), 139.04 (C), 160.45 (C), 164.36 (C), 175.38 (C) and $179.31(\mathrm{C})$.

Preparation of bromoquinone (10). To .a solution of quinone 9 (217 mg, $1 \mathrm{mmol}$ ) in methanol $\left(25 \mathrm{~cm}^{3}\right)$ was added a solution of enamino ester $8(159 \mathrm{mg}, 1 \mathrm{mmol})$ in methanol $\left(5 \mathrm{~cm}^{3}\right)$. The reaction was stirred for a total of approximately $10 \mathrm{~min}$, open to the atmosphere, after which the reaction solution had turned a deep purple colour. The solvent was removed under reduced pressure to produce a dark purple solid. This crude material was purified by flash chromatography with silica gel, eluting with EtOAc/hexane (60: 40). The early fractions gave bromoquinone 10 (272 mg, 73\%) as a deep purple solid, m.p.141-143 ${ }^{\circ} \mathrm{C}$ (from propan-2-ol) (Found: C, 44.5; H, 4.2; N, 3.7; $\mathrm{M}^{+}$, 373.0167. $\mathrm{C}_{14} \mathrm{H}_{16}{ }^{79} \mathrm{BrNO}_{6}$ requires $\mathrm{C}$, 44.9; H, 4.3; N, 3.7\%; M, 373.0161); $v_{\max }(\mathrm{KBr}) / \mathrm{cm}^{-1} 3377,2954,1655,1640,1604,1260,1237$ and 1091; $\delta_{\mathrm{H}} 3.07$ (d, 3H, J = 5.4 Hz, NMe), 3.20 (s, 3H, $\mathrm{CH}_{2}-\mathrm{OMe}$ ), 3.58 (s, 3H, 4-OMe), 3.87 (s, 3H, $\mathrm{CO}_{2} \mathrm{Me}$ ), 3.96 (s, 2H, $\underline{\mathrm{H}}_{2}-\mathrm{OMe}$ ), 6.01 (s, $\left.1 \mathrm{H}, 5-\mathrm{H}\right)$ and 9.45 (br s, $\left.1 \mathrm{H}, \mathrm{NH}\right) ; \delta_{\mathrm{C}} 30.24(\mathrm{NMe}), 50.82\left(\mathrm{CH}_{2^{-}}\right.$

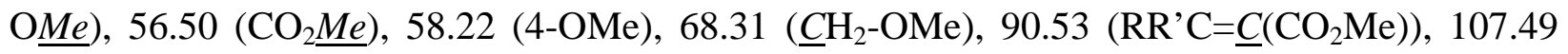
(CH), 135.24 (C), 146.88 (C), 158.39 (C), 159.79 (C), 167.85 (C), 175.24 (C) and 184.05 (C).

The later fractions gave indoloquinone 11 (82 $\mathrm{mg}, 28 \%$ ) as a bright yellow solid. The material was identical (mp, IR, NMR and TLC) to that described below.

Preparation of methyl 6-methoxy-2-methoxymethyl- $N$-methyl-4,7-dioxo-indole-3carboxylate (11). A solution of bromoquinone 10 (100 mg, $0.27 \mathrm{mmol})$ in acetonitrile $\left(10 \mathrm{~cm}^{3}\right)$ containing potassium carbonate (131 mg, $0.95 \mathrm{mmol}$ ) and copper (II) bromide (12 mg, 0.054 mmol) was stirred at room temperature for $24 \mathrm{~h}$. The insoluble material was then removed by filtration through a pad of celite, washing with methylene chloride. The filtrate was evaporated at reduced pressure to produce a crude solid. This crude material was purified by flash chromatography with silica gel, eluting with EtOAc/hexane (30: 70) to afford $\mathbf{1 1}$ as a bright yellow solid (43 mg, 54\%), m.p.153-155 ${ }^{\circ} \mathrm{C}$ (from propan-2-ol) (Found $\mathrm{M}^{+}$, 293.0878. $\mathrm{C}_{14} \mathrm{H}_{15} \mathrm{NO}_{6}$ requires $\mathrm{M}$, 293.0899); $v_{\max }(\mathrm{KBr}) / \mathrm{cm}^{-1} 2924,1711,1686,1644,1595$ and 1200; $\delta_{\mathrm{H}}$ 3.37 (s, 3H, NMe), 3.82 (s, 3H, $\mathrm{CH}_{2}-\mathrm{OMe}$ ), 3.95 (s, 3H, 6-OMe), 4.03 (s, 3H, $\mathrm{CO}_{2} \mathrm{Me}$ ), 4.67 (s, $\left.2 \mathrm{H}, \underline{\mathrm{C}}_{2}-\mathrm{OMe}\right)$ and $5.76(\mathrm{~s}, 1 \mathrm{H}, 5-\mathrm{H}) ; \delta_{\mathrm{C}} 33.51(\mathrm{NMe}), 52.31\left(\mathrm{CH}_{2}-\mathrm{OMe}\right), 56.64\left(\mathrm{CO}_{2} \underline{\mathrm{Me}}\right)$, 58.17 (6-OMe), 62.61 ( $\left.\underline{\mathrm{CH}}_{2}-\mathrm{OMe}\right), 107.91$ (CH), 114.94 (C), 123.81 (C), 128.81 (C), 139.86 (C), 158.76 (C), 164.36 (C), 172.84 (C) and 181.10 (C).

Preparation of 5-methoxy-3-methoxycarbonyl- $N$-methyl-4,7-dioxo-2-indolecarbaldehyde (16). To a solution of quinone 6 (26 mg, $0.089 \mathrm{mmol})$ in a mixture of $\mathrm{CH}_{2} \mathrm{Cl}_{2}: \mathrm{H}_{2} \mathrm{O}, 18: 1\left(8 \mathrm{~cm}^{3}\right)$ was added a suspension of dichlorodicyanobenzoquinone (DDQ) (109 mg, $0.48 \mathrm{mmol}, 5.4 \mathrm{equ}$ ) in a mixture of $\mathrm{CH}_{2} \mathrm{Cl}_{2}: \mathrm{H}_{2} \mathrm{O}, 18: 1\left(8 \mathrm{~cm}^{3}\right)$. Upon addition of the DDQ a colour change was noticed from yellow/orange to black/blue. The suspension was stirred for $20 \mathrm{~min}$ and then taken up in water $\left(7 \mathrm{~cm}^{3}\right)$ and extracted with methylene chloride $\left(3 \times 7 \mathrm{~cm}^{3}\right)$. The organic components were combined, dried $\left(\mathrm{MgSO}_{4}\right)$, filtered and concentrated under reduced pressure to produce a solid residue which was purified by passing through a short pad of silica eluting with 
EtOAc/hexane (40: 60) to produce 16 (22 mg, 88\%) as a yellow solid (Found: $\mathrm{M}^{+}, 277.0581$. $\mathrm{C}_{13} \mathrm{H}_{11} \mathrm{NO}_{6}$ requires $\left.\mathrm{M}, 277.0586\right) ; v_{\max }(\mathrm{KBr}) / \mathrm{cm}^{-1} 1719,1698,1683,1640$ and 1607; $\delta_{\mathrm{H}} 3.88$ (3H, s, NMe), 3.99 (3H, s, 5-OMe), 4.36 (3H, s, $\left.\mathrm{CO}_{2} \mathrm{Me}\right), 5.87(1 \mathrm{H}, \mathrm{s}, 6-\mathrm{H})$ and $10.11(1 \mathrm{H}, \mathrm{s}$, $\mathrm{CHO}) ; \delta_{\mathrm{C}} 34.99$ (NMe), 53.42 ( $\left.\mathrm{CO}_{2} \underline{\mathrm{Me}}\right), 57.31$ (5-OMe), $108.44(\mathrm{CH}), 114.91$ (C), 120.99 (C), 132.28 (C), 137.36 (C), 160.30 (C), 164.66, (C), 174.67 (C), 179.31 (C) and 182.73 (CH).

Preparation of methyl 5-methoxy-3-methoxycarbonyl- $N$-methyl-4,7-dioxo-2-indole acryl ate (EO14) (17). A $25 \mathrm{~cm}^{3}$ round bottomed flask, equipped with a magnetic stirring bar and fitted with a nitrogen inlet and outlet, was thoroughly flame dried under nitrogen. Anhydrous lithium bromide (10 mg, $0.113 \mathrm{mmol}$ ) was weighed in the atmosphere and transferred quickly to the flask with the aid of a solid addition funnel. Dry THF $\left(7 \mathrm{~cm}^{3}\right)$ was then added to the flask. Trimethyl phosphonoacetate $\left(0.15 \mathrm{~cm}^{3}\right.$ of $0.621 \mathrm{M}$ in dry THF, $\left.0.094 \mathrm{mmol}, 1 \mathrm{equ}\right)$ was added and the mixture stirred for $5 \mathrm{~min}$. Triethylamine $\left(0.14 \mathrm{~cm}^{3}\right.$ of $0.723 \mathrm{M}$ in dry THF, $0.103 \mathrm{mmol}$, $1.1 \mathrm{equ})$ was then added and the mixture stirred for an additional $10 \mathrm{~min}$. After this time the aldehyde 16 (26 mg, $0.094 \mathrm{mmol}$ ) in THF $\left(3 \mathrm{~cm}^{3}\right)$ was added dropwise and the reaction mixture stirred for $2.5 \mathrm{~h}$. The reaction was quenched with aqueous $\mathrm{HCl}$ ( $1 \mathrm{ml}$ of $0.1 \mathrm{~mol}$ solution) and extracted with methylene chloride $\left(3 \times 10 \mathrm{~cm}^{3}\right)$. The organic extracts were combined, dried $\left(\mathrm{MgSO}_{4}\right)$, filtered and the solvent removed under reduced pressure. This crude material was purified by wet flash chromatography (elution, EtOAc: hexane 40: 60) to afford the title compound 17 (28 mg, 90\%) as an orange solid, m.p. 226-228 ${ }^{\circ} \mathrm{C}$ (from propan-2-ol) (Found: $[\mathrm{M}+\mathrm{Na}]^{+}$, 356.0752. $\mathrm{C}_{16} \mathrm{H}_{15} \mathrm{NNaO}_{7}$ requires $\left.\mathrm{M}, 356.0746\right) ; v_{\max }(\mathrm{KBr}) / \mathrm{cm}^{-1} 1713,1686,1634$, 1600 and 1217; $\delta_{\mathrm{H}} 3.82$ (s, 3H, NMe), 3.84 (s, 3H, C=CCO $\mathrm{CCO}_{2} \mathrm{Me}$ ), 3.95 (s, 3H, 3-CO $\mathrm{CO}_{2} \mathrm{Me}$ ), 4.08 (s, $3 \mathrm{H}, 5-\mathrm{OMe}$ ), 5.76 (s, 1H, 6-H), 6.50 (d, 1H, J = $16 \mathrm{~Hz}, \mathrm{CH}=\mathrm{C}_{\mathbf{H C O}} \mathrm{Me}$ ) and 7.65 (d, 1H, J = 16 $\mathrm{Hz}, \mathrm{C} \underline{H}=\mathrm{CHCO}_{2} \mathrm{Me}$ ); $\delta_{\mathrm{C}} 33.59(\mathrm{NMe}), 52.17$ (3- $\mathrm{CO}_{2} \underline{\mathrm{Me}}$ ), $52.85\left(\mathrm{C}=\mathrm{CCO}_{2} \underline{\mathrm{Me}}\right.$ ), 56.75 (5-OMe), 107.32 (CH), 116.40 (C), 121.99 (C), 124.35 (CH), 129.05 (CH), 130.47 (C), 134.62 (C), 160.30 (C), 164.64 (C), $166.32(\mathrm{C}), 175.27(\mathrm{C})$ and $178.84(\mathrm{C})$.

\section{References}

1. Navlor, M. A.; Jaffar, M.; Nolan, J.; Stephens, M. A.; Butler, S.; Patel, K. B.; Everett, S.A.; Adams, G. E.; Stratford, I. J. J. Med. Chem. 1997, 30, 2335.

2. Robertson, N.; Haigh, A.; Adams, G. E.; Stratford, I. J. Eur. J. Cancer 1994, 69, 57.

3. Aamdal, S.; Lund, B.; Koier, I.; Houten, M.; Wanders, J.; Verweij, J. Cancer Chemother. Pharmacol. 2000, 45, 85.

4. (a) Murphy, W. S.; O’ Sullivan, P. J. Tetrahedron Lett. 1992, 33, 531 and refs. therein. (b) Knölker, H.; Reddy, K. R. Chem. Rev. 2002, 102, 4303.

5. Giles, R.G. F.; Hughes, A. B.; Sargent, M. B. J. Chem. Soc., Perkin Trans. 1 1991, 1581.

6. For similar procedures see Glickman, S. A.; Cope, A. C. J. Am. Chem. Soc. 1945, 67, 1017.

7. Blatchy, J. M.; Green, R. J. S.; McOmie, J. F. W.; Searle, J. B. J. Chem. Soc. C 1969, 1353.

8. Comer, E., Ph.D. Thesis, National University of Ireland, 2003. 
9. Luly, J.R.; Rapoport, H. J. Am. Chem. Soc. 1983, 105, 2859.

10. Dudek, G.O.; Volpp, G. P. J. Am. Chem. Soc. 1963, 85, 2697.

11. Baldwin, J. E. J. Chem. Soc. Chem. Commun. 1976, 734.

12. Oostveen, E. A.; Speckamp, W. N. PCT Int. Appl. WO 8706227, 1987; Chem Abstr. 1988, 109, 22842; see also, Oostveen, E.A.; Speckamp, W.N. Tetrahedron 1987, 43, 255.

13. Oikawa, Y.; Yoshioka, T.; Yonemitsu, O. Tetrahedron Lett. 1982, 23, 885 and references therein.

14. Rathke, M. W.; Nowak M. J. Org. Chem. 1985, 50, 2624.

15. (a) Kinugawa, M.; Arai, H.; Nishikawa, H.; Sakaguchi, A.; Ogasa, T.; Tomioka, S.; Kasai, M., J. Chem. Soc., Perkin Trans. 1 1995, 2677. (b) Kinugawa, M.; Masuda Y.; Arai, H.; Nishikawa, H.; Ogasa, T.; Tomioka, S.; Kasai, M. Synthesis 1996, 633.

16. Cotterill, A. S.; Moody, C. J.; Roffey, J. R. A. Tetrahedron 1995, 51, 7223. 